УДК 338.24

\title{
КЛАСИФІКАЦІЯ ОСНОВНИХ ВИДІВ АНАЛІЗУ ВИГІД ТА ВИТРАТ
}

\section{CLASSIFICATION OF THE MAIN TYPES OF COST-BENEFIT ANALYSIS}

\author{
Кібук Тетяна Миколаївна \\ кандидат економічних наук, доцент, \\ ДВНЗ «Київський національний економічний університет \\ імені Вадима Гетьмана» \\ ORCID: https://orcid.org/0000-0001-6753-2579
}

\author{
Kibuk Tetyana \\ SHEE "Kyiv National Economic University named after Vadim Hetman"
}

\begin{abstract}
Стаття присвячена питанням вивчення одного з найбільш актуальних та широко використовуваних інструментів процесу прийняття рішень - аналізу вигід та витрат (ABB). Досліджено витоки виникнення аналізу вигід та витрат. Проаналізовано та систематизовано підходи до класифікації основних видів аналізу вигід та витрат. Виокремлено різновиди аналізу вигід та витрат в залежності від часу його використання в аналізованому проекті чи економічному курсі. Здійснено порівняння таких видів аналізу вигід та витрат, як фрінансовий та економічний. Проаналізовано переваги та недоліки кожного з видів аналізу вигід та витрат. Досліджено головні ссрери використання аналізу вигад та витрат, зокрема найбільш нової ссрери - екологічного аналізу. Окреслено місце аналізу вигід та витрат в процесі прийняття рішень та виділено основні його види в цьому процесі.

Ключові слова: аналіз вигід та витрат, ex ante $A B B$, ex post $A B B$, in medias res $A B B$, економічний $A B B$, фрінансовий $\mathrm{ABB}$, екологічний $\mathrm{ABB}$, комплексний $\mathrm{ABB}$, індексний $\mathrm{ABB}$, аналіз економічної ефективності.
\end{abstract}

Статья посвящена вопросам изучения одного из наиболее актуальных и широко используемых инструментов процесса принятия решений - анализа выгод и затрат (АВЗ). Исследовано истоки возникновения анализа выгод и затрат. Проанализированы и систематизированы подходы к классификации основных видов анализа выгод и затрат. Выделены разновидности анализа выгод и затрат в зависимости от времени его использования в рассматриваемом проекте или экономическом курсе. Проведено сравнение таких видов анализа выгод и затрат, как фринансовый и экономический. Проанализированы преимущества и недостатки каждого из видов анализа выгод и затрат. Исследованы главные ссреры использования анализа выгод и затрат, в частности наиболее новой сферы - экологического анализа. Определены место анализа выгод и затрат в процессе принятия решений и выделены основные его виды в этом процессе.

Ключевые слова: анализ выгод и затрат, ex ante AB3, ex post AB3, in medias res AB3, экономический AB3, финансовый АBЗ, экологический АBЗ, комплексный AB3, индексный АBЗ, анализ экономической эфффективности.

The article is devoted to the study of one of the most relevant and widely used tools of the decision-making process - cost-benefit analysis (CBA). The origins of the cost-benefit analysis since the 19th century and the output of this analysis to the level of use in government decision-making have been studied. Approaches to the classification of the main types of cost-benefit analysis by various factors are analyzed and systematized. There are different types of cost-benefit analysis depending on the time of its use in the analyzed project or economic course, namely: ex ante, ex post, in medias res CBA's and CBA, which compares previous analyzes. Their weaknesses and limits of use in decision-making are generalized, the level of uncertainty necessary for each information of this analysis is analyzed. The types of cost-benefit analysis by areas of application are systematized, among which economic, financial and ecological CBA are studied. A comparison of such types of cost-benefit analysis as financial and economic is carried out. The main purpose, tools for each of these analyzes, as well as the main benefits, costs, prices and discount rates used in financial and economic CBA are identified. The advantages and disadvantages of each of these types of cost-benefit analysis are analyzed. The main areas of use of cost-benefit analysis, in particular the newest area - ecological CBA, are summarized and its role in project research is analyzed. The place of cost-benefit analysis in the decision-making process is outlined and its main types depending on the tools used in this process are identified, among which the following are highlighted: complex, index CBA and cost-effectiveness analysis. 
The strengths and weaknesses of these types of cost-benefit analysis are systematized, as well as the areas of application of complex and index analysis in the decision-making process are highlighted. The question of distinguishing between the analysis of economic efficiency and the cost-benefit analysis is investigated. Further directions of research on the issue of studying the cost-benefit analysis are identified.

Keywords: cost-benefit analysis, ex ante CBA, ex post CBA, in medias res CBA, economic CBA, financial CBA, ecological CBA, complex CBA, index CBA, economic efficiency analysis.

Постановка проблеми. 3 розвитком інфрормаційних технологій все гостріше постає питання необхідності швидко приймати рішення, які до того ж мають бути раціонально обґрунтованими. Для цього використовуються найбільш сучасні інструменти, одним з яких є аналіз вигід і витрат. У зв'язку з цим суттєвої уваги потребує дослідження різновидів АBВ та меж застосування останніх в процесі прийняття рішень на рівні як приватних підприємств, так і на державному рівні, що робить дане питання все більш актуальним.

Аналіз останніх досліджень та публікацій. Дослідженню проблеми виокремлення та аналізу різних видів аналізу вигід та витрат присвячені роботи багатьох міжнародних науковців та дослідників, серед яких слід виділити: Ентоні Е. Боардмен, Девід Х. Грінберг, Ейдан Р. Вайнінг, Девід Л. Веймер, Gerbert Romijn, Gusta Renes та ін.

Виділення невирішених раніше частин загальної проблеми. Незважаючи на те, що питання дослідження видів аналізу вигід та витрат є предметом багатьох досліджень, на разі не вирішеною є проблема розробки структурованої класиорікації різних видів даного аналізу з урахуванням різних класифікаційних фракторів та виділенням місця кожного виду в практичній діяльності.

Формулювання цілей статті (постановка завдання). Головним завданням цієї роботи є систематизація та узагальнення існуючих різновидів аналізу видів і витрат з урахуванням сучасних тенденцій в процесі прийняття рішень.

Виклад основного матеріалу дослідження. В останній час одним 3 найбільш раціональних методів ухвалення рішень $є$ аналіз вигід і витрат (Cost-Benefit analyzis). Даний аналіз був заснований на концепції раціонального вибору, виходячи з якої має вибиратись альтернатива з вигодами, що перевищують витрати.

Історія аналізу вигод і витрат (далі ABB) показує, як його теоретичне походження сходить до питань оцінки інфрраструктури у Франції у XIX столітті. Теорія економіки добробуту розвивалася разом 3 «граничною» революцією в мікроекономічній теорії в пізньому XIX столітті, кульмінацією якої стала еконо- міка добробуту Пігу в 1920 році, яка ще більше формалізувала поняття розходження приватних і соціальних витрат, та «нову економіку добробуту» 1930-х років, яка реконструювала економіку добробуту лише на основі порядкової корисності. Проте, теорія та практика залишалися невідповідними, доки офіційна вимога щодо порівняння витрат та вигід не була введена в інвестиції, пов'язані $з$ водою, у США наприкінці 1930-х років. Після Другої світової війни існував тиск на «ефективність уряду», і пошук був спрямований на те, щоб забезпечити ефективне використання державних коштів у великих державних інвестиціях. Це призвело до початку злиття нової економіки добробуту, яка, по суті, була аналізом витрат та вигід, і практичним прийняттям рішень. 3 1960-х років АВВ користувався коливаннями, але тепер визнається основним методом оцінки державних інвестицій та державної політики.

Протягом історії використання АВВ розрізнялись різні інструменти використання останнього, що спричинило виділення різних його видів. Тому виникла необхідність в класифікації останніх.

Одним з основних підходів до класифрікації аналізу вигід та витрат $€$ класифікація видів $\mathrm{ABB}$ за часом виконання останнього, виходячи 3 того, коли приймається рішення по обраному проекту. За такою ознакою різні автори виділяють два [1], три [2] або чотири види [3]. Найбільшого розповсюдження набуло виділення чотирьох основних видів АВВ згідно до Ентоні Е. Бордмана:

1. Ex ante ABB (інша назва: заснований на використанні очікуваних величин) здійснюється до початку реалізації проекту або економічного курсу, коли потрібно вирішити чи варто вкладати кошту в даний проект. Ex ante допомагає прийняти раціональне рішення щодо необхідності реалізації окремого проекту або вибрати найкращий з кількох проектів до того, як він фактично розпочнеться. Основною перевагою такого виду аналізу є внесення суттєвого внеску в питання оптимального розподілу ресурсів. Крім того, такий Ex ante ABB дозволяє швидко прийняти рішення. Однак недоліком цього виду аналізу 
$€$ високий ступень невизначеності щодо майбутніх витрат та вигід проекту, базування на слабкій інорормації.

2. Ex post ABB (інша назва: заснований на використанні сподіваних величин) здійснюється вже після реалізації проекту або економічного курсу. Під час здійснення даного аналізу вже всі витрат розглядаються, як незворотні, що пов'язано 3 неможливістю повернути раніше витрачені кошти. Перевагою Ex post ABB $€$ базування на менш спекулятивній інформації (оскільки всі витрати та вигоди вже відбулися), можливість визначення дійсної цінності проекту, а також порівнянні цінності цього проекту з іншими альтернативними проектами. Серед недоліків можна виділити: меншу силу впливати на розподіл ресурсів для поточного проекту. Але результати такого АВВ можуть вплинути на розподіл ресурсів для подібних майбутніх проектів.

3. In medias res ABB (інша назва: у ході проекту) здійснюється під час реалізації проекту або економічного курсу. В такому аналізі спостерігаються риси двох попередніх видів аналізу. Під час впровадження АВВ має на меті надати керівникам програм чи проектів інфрормацію про те, як здійснюється реалізація стосовно запланованих 3 точки зору фізичних цілей та їх відповідних переваг, а також витрат на реалізацію. На цьому етапі проекту результати аналізу, як правило, корисні для визначення сорер, які потребують особливої уваги, та для перегляду варіантів управління проектом відповідно до його цілей та завдань протягом другої половини. Перевагою цього АВВ $є$ низькі незворотні витрати, що дозволяє, при необхідності, переміщувати ресурси з одного проекту на інший. Основним недоліком такого аналізу $є$ необхідність продовження реалізації обраного проекту за наявності великих незворотних витрат.

4. АВB, що порівнює аналіз еx ante з аналізом ex post або 3 in medias res. Такий аналіз не всі дослідники виокремлюють, як окремий різновид. Але даний вид аналізу дозволяє оцінити ефективність АВB як основного інструменту для прийняття рішень. На даний момент, практично немає об'єктивних опублікованих прикладів цього типу аналізу вигід і витрат. Проте, тільки цей аналіз надає найповнішу інформацію про всі помилки і точність ABB для схожих проектів.

ще одним підходом до класифрікації аналізу вигід і витрат є виокремлення його видів за сферою застосування на даний час виокремлюють три основні різновиди АВВ:
1. Фінансовий аналіз вигід та витрат має найбільше поширення у світі бізнесу. Зокрема, приватний сектор має суттєвий інтерес до фрінансового аналізу та планує забезпечити прийняття належних бізнес-рішень [2]. Основною задачею такого ABB $є$ оцінка того, як і якою мірою додаткові чисті потоки фрінансових вигід, які отримані в результаті інвестицій у проект, відповідають інвестиційним витратам та операційним витратам за даний період. Фінансовий аналіз вигід і витрат оцінює ефрективність інвестицій, порівнюючи ефективні фрінансові витрати та вигоди з точки зору інвестора. Крім того, структуровані фрінансові моделі для даного виду АВВ можуть служити основою для побудови моделей економічних потоків для економічного аналізу вигід та витрат [2].

Отже, головною метою фрінансового АВВ $\epsilon$ есрективність приватних інвестицій. Аналіз використовує прогнози грошових потоків для проекту, щоб оцінити фрінансову придатність програми чи проекту. Він включає розрахунок внутрішньої фрінансової норми прибутку (IRR) та фрінансової чистої теперішньої вартості (NPV).

Фінансовий АВВ фокусується на чистому прибутку для приватних груп або індивідуумів. Оцінює, чи генерує проект достатню фрінансову віддачу для задоволення відповідних інвестиційних та експлуатаційних витрат. Він виконується з точки зору інвестора. Тут використовуються ринкові ціни. Включає есрективні грошові витрати та вигоди. В якості основних вигід розглядаються ринкові товари та послуги. В якості ціни в аналізі використовуються ринкові ціни, тобто ціну придбання або продажу товарів чи послуг на ринку.

Крім того, в даному виді АВВ ставкою дисконтування $€$ ринкова ставка дисконтування, яка відображає альтернативні витрати капіталу на фрінансовому ринку. При цьому, розподіл вигід в фрінансовому АВВ не викликає жодних проблем для аналітика.

2. Економічний аналіз вигід та витрат має найбільше поширення в прийнятті рішень на державному рівні. Основною задачею економічного АВВ $€$ сприяння більш есрективному розподілу ресурсів, демонструючи економічну вигоду від даного проекту або програми для суспільства в цілому у порівнянні з існуючими альтернативами. Даний вид аналізу здійснюється 3 точки зору суспільства в цілому, а не з точки зору інвестора, як в попередньому виді АВВ.

Головною метою економічного АBB $\epsilon$ ефективність державних інвестицій. Аналіз використовує прогнози економічних потоків витрат та вигід від програми чи проекту для оцінки їх еко- 
номічної придатності. Він включає розрахунок внутрішньої економічної норми прибутку (IRR) та економічної чистої теперішньої вартості (NPV).

Економічний АBВ фрокусується на чистій віддачі для суспільства в цілому. Оцінює внесок проекту в економічне благополуччя 3 точки зору суспільства у розглянутому регіоні чи країні. В аналізі використовуються економічні цінності (тіньові ціни), які виражають вартість, яку суспільство готове заплатити за товари чи послуги. Включає альтернативні витрати або вигоди для суспільства в цілому [2]. Вони можуть відрізнятися від фрінансових витрат або вигід, які розглядаються в фрінансовому АВВ, оскільки:

- ринкові ціни відрізняються від тіньових цін, які отримуються з використанням соціального коефріцієнта перерахунку, що виправляє спотворення цін, спричинене провалом ринку;

- вони включають зовнішні фрактори, що породжують соціальні витрати та вигоди, що не враховуються в фрінансовому АВВ, оскільки вони не приносять реальних грошових витрат або доходу (наприклад, вплив на навколишнє середовище або наслідки перерозподілу);

- вони виключають субсидії та непрямі податки на проміжне споживання та вироблені товари та послуги.

В якості ціни в аналізі можуть використовуватися ринкові, адміністративні або тіньові (скориговані або призначені) ціни [1]. В економічному ABB ставкою дисконтування $\epsilon$ соціальна дисконтна ставка. Вона відображає альтернативні витрати капіталу, який вилучається з економіки для фрінансування проекту. Тож, розподіл вигід в даному виді аналізу не $€$ основною проблемою, але може викликати труднощі в окремих випадках аналізу.

3. В останні роки деякі дослідники виокремлюють ще один вид АBВ, а саме екологічний аналіз вигід і витрат. Екологічний $\mathrm{ABB}$ - це застосування аналізу вигід та витрат до проектів чи політичних рішень, які мають на меті покращення навколишнього середовища або дії, які якимось чином впливають на природне середовище як непрямий наслідок [4, с. 3]. Це вимагає розуміння того, що ці варіанти забезпечують з точки зору вигід (визначених як збільшення добробуту людини) та витрат (визначених як зменшення добробуту людини). Отже, роль екологічного АВВ полягає в тому, щоб виступати інструментом для розгляду соціальної ефективності рішень у рамках більш широкого політичного процесу.

ABB $€$ одним 3 основних інструментів в процесі прийняття рішень. Різні етапи про- цесу прийняття рішень пред'являють різні вимоги до аналізу вигід та витрат. Вимоги, що пред'являються до АВВ, різняться залежно від стадії процесу прийняття рішень, тоді як можливості скласти аналіз залежать від наявної інфрормації.

Не менш важливої сфрерою застосування аналізу вигід та витрат є його використання в процесі прийняття рішень, як на рівні підприємства, так і на державному рівні. Отже, на практиці в залежності від інструментів, що використовуються в процесі прийняття рішення, розрізняють три типи $\mathrm{ABB}$ [5, с. 39]:

1) Комплексний $A B B$, в якому всі етапи дослідження виконуються в повному обсязі, i всі ефректи ідентифрікуються, вимірюються та оцінюються якомога точніше. Цей тип аналізу вигід та витрат містить найкращу доступну інформацію та пропонує особам, що приймають рішення, найдетальніше уявлення про переваги та недоліки того чи іншого заходу. Основним недоліком таких ABB $€$ обсяг досліджень, що може зробити дослідження довгим та дорогим для проведення.

2) Індексний $A B B$, в якому визначення есректів та оцінок $€$ менш точним і базується на правилах великих пальців та номерів індексів. Перевага індексних аналізів полягає в тому, що вони швидші та дешевші, ніж комплексні $A B B$, що робить їх можливими для менших заходів, оскільки вартість дослідження може бути пропорційною вартості самого заходу. Менші витрати на дослідження індексних аналізів вигід та витрат також роблять їх корисним інструментом, коли існує багато альтернатив проекту, які слід дослідити. Їх недоліком $€$ те, що інорормація, яку вони надають, $є$ менш детальною та низькою за якістю, ніж у комплексних АВB.

У міру того, як стає доступною більше інформації про оцінювання та його ефекти, ABB стає все більше схожим на комплексний ABB. Однак, як правило, завжди існують менш важливі ефекти, які можна оцінити за допомогою індексних чисел або описати якісно на основі гіпотези.

3) Особливою фрормою аналізу вигід та витрат є аналіз економічної есрективності. Ці аналізи фрокусуються на єдиному (немонетизованому) есректі та порівнюють витрати різних варіантів політики для досягнення цього есректу. Це означає, що мета політики не є спірною і не $є$ предметом дослідження. Таким чином, такий аналіз можна вважати ABB з фріксованим ефректом; іншими словами, ступінь досягнення цілі політики визначається зазда- 
легідь. Однак загальна структура аналізу економічної ефрективності мало чим відрізняється від аналізу вигід та витрат, а методи та принципи дослідження однакові.

Між аналізом економічної ефрективності та АВВ існує сіра зона відповідно до того, наскільки вузько визначена мета, яку потрібно досягти. Аналіз вигід та витрат, в якому альтернативи (включаючи нульову альтернативу) призначені для досягнення вузько визначеної мети, насправді $€$ аналізом еокномічної ефективності [5, с. 41].

Висновки. Як видно з дослідження основних видів аналізу вигід та витрат, за останнє десятиліття відбулося багато нових теоретичних розробок і значне розширення використання ABB та його політичних та інвестиційних застосувань. Зокрема даний аналіз почав застосовуватися і в таких нових сорерах, як аналіз екологічних проектів навіть на державному рівні. Через поширення $A B B$ на державний рівень вивчення особливостей використання аналізу вигід та витрат в різних сорерах діяльності, а також дослідження етапів його проведення набуває все більшої уваги, що буде основою для подальших розробок автора статті та інших економістів та дослідників.

\section{СПИСОК ВИКОРИСТАНИХ ДЖЕРЕЛ:}

1. A Student's Guide to Cost Benefit Analysis for Natural Resources. URL: https://cals.arizona.edu/classes/ rnr485/ch3.htm

2. Module 5: Fiscal Financial and Economic Analysis (FFEA). URL: http://www.fao.org/in-action/herramientaadministracion-tierras/module-5/practical-evaluation-guide/introduction-cba/en/

3. Ентоні Е. Боардмен, Девід Х. Грінберг, Ейдан Р. Вайнінг, Девід Л. Веймер. Аналіз вигід і витрат. Концепція і практика : Пер. з англ. Київ : Видавництво «АртЕк», 2003. 568 с.

4. Cost-Benefit Analysis and the Environment: Further Developments and Policy Use: OECD Publishing, Paris, 2018. URL: https://www.oecd.org/env/tools-evaluation/CBA-brochure-web.pdf

5. Romijn G., Renes G. General guidance for Cost-Benefit Analysis: CPB/PBL, The Hague, 2013. URL: https://www.cpb.nl/sites/default/files/publicaties/download/cba-guidance.pdf

\section{REFERENCES:}

1. A Student's Guide to Cost Benefit Analysis for Natural Resources. Available at: https://cals.arizona.edu/ classes/rnr485/ch3.htm

2. Module 5: Fiscal Financial and Economic Analysis (FFEA). Available at: http://www.fao.org/in-action/ herramienta-administracion-tierras/module-5/practical-evaluation-guide/introduction-cba/en/

3. Anthony E. Boardman, Devid H. Greenberg, Aidan R. Vining, David L. Weimer (2003). Analiz vigid i vitrat. Kontseptsiya i praktika [Cost-Benefit Analysis: Concepts and Practice]: Per. z angl. Kyïv: Vidavnitstvo «ArtEK», 568 p. (in Ukrainian)

4. Cost-Benefit Analysis and the Environment: Further Developments and Policy Use: OECD Publishing, Paris, 2018. URL: https://www.oecd.org/env/tools-evaluation/CBA-brochure-web.pdf

5. Romijn G., Renes G. General guidance for Cost-Benefit Analysis: CPB/PBL, The Hague, 2013. URL: https://www.cpb.nl/sites/default/files/publicaties/download/cba-guidance.pdf 